\title{
Evidence of Climate and Environmental Change in Nigeria: Synthesis from the Driving Force, Pressure, State, Impact and Response (DPSIR) Framework
}

\author{
Christopher Ndabula (Corresponding author) \\ Federal University Dutsin-Ma, \\ Department of Geography and Regional Planning, \\ PMB 5001, Dutsin-Ma, Katsinate State, Nigeria \\ Tel: +234-7065817224 E-mail: cndabula@fudutsinma.edu.ng \\ Fanen Terdoo \\ Federal University Dutsin-Ma, \\ Department of Geography and Regional Planning, \\ PMB 5001, Dutsin-Ma, Katsinate State, Nigeria \\ Tel: +234-8053288794 E-mail: fterdoo@,fudutsinma.edu.ng \\ Godwill Geofrey Jidauna \\ Federal University Dutsin-Ma, \\ Department of Geography and Regional Planning, \\ PMB 5001, Dutsin-Ma, Katsinate State, Nigeria \\ Tel: +234-7066099392 E-mail: gjidauna@fudutsinma.edu.ng
}

ORCID ID: Christopher Ndabula https://orcid.org/0000-0001-8272-6777

ORCID ID: Godwill Geofrey Jidauna

https://orcid.org/000 0001-7589-0624

\begin{abstract}
This review employs the DPSIR framework to synthesise evidence of climate and environmental change in Nigeria. The study identified population, political, social, economic, and technological dynamics as the major drivers of human activities with indicators being land-use, water-use, and energy-use dynamics. . Land-use and water-use, for example, which involve direct exploitation of land resources, result in landcover dynamics. The rate, extent, and magnitude of human activities are the proximate or direct factors that exert pressure on the environment, particularly loss of vegetation cover and thus $\mathrm{CO}_{2}$ and other GHG sinks, whereas energy-use results in increased $\mathrm{CO}_{2}$ and other $\mathrm{GHG}$ emissions. This double tragedy is a direct contributor to climate and environmental change. Total energy consumption has increased in Nigeria, where both spatial and temporal variations in air temperature distribution have been observed, with the trend revealing that mean temperature has shown a rise of about $1.2^{\circ} \mathrm{C}$ along the coastal cities and $2^{\circ} \mathrm{C}$ in extreme northern Nigeria. The observable state and trends of the Nigerian environment include an increase in temperature and an increase in extreme weather events. Droughts and desertification have persisted, as has the frequency, amount, duration, and intensity of rainfall, as well as changes in landuse/landcover. As a result, 70-80 percent of Nigeria's original forest has vanished. As the area of Lake Chad has shrunk, an increasing number of fauna (primates) and flora biodiversity are threatened or endangered. Crop and livestock productivity declines or is lost, as are rural livelihoods, infrastructure, tourist potentials, the agro-based manufacturing sector, the energy sector, and increased food insecurity. The current state and trend of climate and environmental change in Nigeria has prompted responses, mitigation, and adaptation in order to increase resilience, adaptive capacity, or reduce vulnerabilities and risk.
\end{abstract}

Keywords: Climate change, Environmental change, Greenhouse gases, Flooding, Land cover

DOI: $10.7176 / \mathrm{JEES} / 11-7-05$

Publication date:July $31^{\text {st }} 2021$ 


\section{INTRODUCTION}

Climate change has emerged as one of the most significant environmental issues confronting countries around the world, and many policymakers are gradually recognizing it as a top priority (Jalloh, 2013). There is compelling scientific evidence that the earth's atmosphere is changing faster now than at any other time in human history as a result of sustained greenhouse gas emissions (GHGs) from anthropogenic activities (Rockström et al., 2009; Steffen et al., 2011; Ndabula et al., 2014). Although global climate change and variability have become more pronounced, there is significant variation across geographic areas.

According to the Fourth Assessment Report of the Intergovernmental Panel on Climate Change, Africa's climate will likely remain warmer than the global average, and annual rainfall on the continent is expected to fluctuate throughout the twenty-first century (Niang, I. et al., 2014). Across Sub-Saharan Africa and Nigeria, increase $\mathrm{CO}_{2}$ concentration is believed to have resulted to warming across diverse geographical regions and eco-climatic zones (Figure 1), altering rainfall patterns, including total amount received and distributed seasonally (Abiodun, Lawal, Salami, \& Abatan, 2013a; Niang, et al., 2014; Ogungbenro \& Morakinyo, 2014; Oguntunde, Abiodun, \& Lischeid, 2011; Olaniran, 1991a).

According to Adesina and Odekunle (, n.d); Oladipo, (1993); and Ndabula et al. (2013) reported that the impacts of climate change on Africa are much more extreme due to the economy's vulnerability to climate change and a lack of capacity to adapt. As a result, extreme climatic change events including heavy flooding (Ndabula et al., 2012a), water and heat stress (Jidauna et al., 2016), shortages and droughts, and sea level rise are becoming more frequent (Ayanlade et al., 2018; Oloruntade et al., 2017). With negative consequences affecting all sectors of Nigeria's economy, including agriculture, transportation, telecommunications, and power infrastructure (BNRCC (Building Nigeria's Response to Climate Change Project), 2011; Cervigni \& World Bank, 2013).

Given the current challenges faced by climate and environmental change in Nigeria, it is essential to improve understanding in order to devise successful policies and initiatives to build resilience to the effects of climate and environmental change. Although evidence for climate and environmental change can be found in a variety of studies conducted across Nigeria, they are rarely brought together to form a comprehensive image or shed light on the existence and scale of both. This study explores the main driving forces, environmental pressures, the state of the Nigerian environment in space and time, and the impacts these driving forces, environmental pressures, and the state of the climate and environment have inflicted on Nigerians through a thorough synthesis of indicators using the DPSIR system to bridge this gap. This review is organized into five sections. The following section provides context by describing Nigeria's physical and socioeconomic settings. This is followed by a section with information to help you understand the DPSIR framework and its applications. Then comes the results section, which synthesized evidence of climate and environmental change using the DPSIR framework, followed by a conclusion.

\section{NIGERIA'S PHYSICAL AND SOCIO-ECONOMIC SETTING}

\subsection{Physical Setting}

\subsubsection{Location and Extent}

Nigeria is located on the west coast of Africa between latitudes $40^{\circ} 16^{\prime} \mathrm{N}$ and $14^{\circ} 37^{\prime} \mathrm{E}$ and longitudes $2^{\circ}$ to $15^{\circ} \mathrm{E}$ (approx.. $4^{\circ}$ to $14^{\circ} \mathrm{N}$ and $2^{\circ}$ to $15^{\circ} \mathrm{E}$ ), near the extreme inner corner of the Gulf of Guinea (Figure 2). Nigeria occupies an area of $923,768 \mathrm{sq}$. $\mathrm{km}(356,669 \mathrm{sq}$. mi) with approximately $13,000 \mathrm{~km} 2(1.4 \%)$ of the land covered by water and the remaining $98.6 \%$ by land. (Abiodun, Lawal, et al., 2013) The country has a total boundary length of 4,900 km (3,045 mi) of which $853 \mathrm{~km}(530 \mathrm{mi})$ is coastline.

\subsubsection{Topography}

Nigeria's terrain is characterized by plains in the north and south, which are punctuated by plateaus and hills in the center (Figure 1). The Sokoto Plains are located in the country's northern corner, while the Borno Plains in the northeastern part stretch all the way to the Lake Chad basin. Nigeria has two main relief zones: high plateaux ranging from 300 to more than 900 meters above sea level, and low plateaux ranging from 300 to more than 900 
meters above sea level (Pham-Duc et al., 2020). The Niger-Benue basin, Lake Chad basin, and Gulf of Guinea basin are the three major drainage regions in Nigeria. Short rivers pour into the Gulf of Guinea, draining the coastal areas. The country's coastline is about 853 kilometers long, with roughly $80 \%$ of it located in the Niger Delta region.

\subsubsection{Eco-Climatic}

Nigeria spans different climatic and ecological zones (Figure 2). The variable climatic conditions and physical features have endowed Nigeria with a very rich biodiversity. The country's rich fauna is also as a result of the diverse vegetation types these ecosystems. These varieties of ecosystems range from rainforests in the south to moist savannah in the central part of the country.

The climate in Nigeria is characterized by relatively high temperature and variations in the amount of precipitation throughout the year with alternating two seasons. The rainy season is generally from April to October and the dry season from November to March. The mean annual rainfall ranges from about $450 \mathrm{~mm}$ in the north east to about $3500 \mathrm{~mm}$ in the coastal south east, with rain falls within 90 to 290 days respectively (Abiodun, et al., 2013). Annually, the average temperature ranges from 21 to $32^{\circ} \mathrm{C}$ in the south while the north has a temperature range of 13 to $41^{\circ} \mathrm{C}$ (Ogunjobi et al., 2018). The mean annual temperature ranges from $27^{\circ} \mathrm{C}$ in the south to $30^{\circ} \mathrm{C}$ in the north with extreme of $14^{\circ} \mathrm{C}$ and $45^{\circ} \mathrm{C}$ and an altitude range of $0-1000 \mathrm{~m}$ above sea level.

\subsection{Socio-Economic Setting}

\subsubsection{Population}

Nigeria had a population of over 140 million in 2006. The population is predicted to be around 206 million people in 2020 at the current rate of 2.62 percent (See

also Figure 4 below) (Population Reference Bureau, 2018). The population distributed unevenly over the country, with around 65 percent residing in rural areas and the rest in urban regions.

\subsubsection{Agriculture}

In Nigeria, agriculture remains the bedrock of the economy as it provides a living for the majority of its populace. World Bank reported that the agricultural sector alone accounts for 33\% of the total GDP of Nigeria and the sector employs around $23 \%$ of its total economically active population (Bosello et al., 2018). The dry northern savannah is appropriate for sorghum, millet, maize, groundnuts, and cotton. Cash crops like oil palm, cocoa and rubber can be grown in the South. Low-lying and seasonal flooded areas can grow rice. The country has 68 million hectares of arable land, abundant freshwater resources covering about 12 million hectares, and an ecological diversity which enables the country to produce a wide variety of crops (Bashir \& Kyung-Sook, 2018).

\section{UNDERSTANDING DPSIR FRAMEWORK AND ITS APPLICATIONS}

This study employs a Driver-Pressure-State-Impact-Response (DPSIR) framework. The DPSIR framework was developed by the Organization for Economic Cooperation and Development to aid in decision making and research (Bidone \& Lacerda, 2004). DPSIR stands for: Driving force (D); Pressure (P); State (S); Impacts (I); and Responses (R.) (Figure 3).

Drivers are the social, demographic and economic developments in societies. They are often defined as socioeconomic sectors that fulfill human needs for food, water, shelter, health, security and culture. They can originate and act at globally, regionally or locally scales.

Pressure on the environment can be caused by intentionally or unintentionally human activities. These include: land use changes, resource consumption, release of substances and physical damage through direct contact on the environment and depends on the kind and level of technology involved in the human activities (Domínguez-Gómez, 2016).

The State of the environment is the condition of the abiotic and biotic components of the ecosystems. The change in quantity and quality of physical, biological and chemical variables can alter the state of the environment by temperature, $\mathrm{CO}_{2}$ concentrations, habitat, species, biodiversity and many others (Amthor, 2001).

Impacts is when the welfare and well-being of humans is compromised due to changes in the quality and 
functioning of ecosystem services. Ecosystem goods and services are ecosystem functions or processes that directly or indirectly benefit human social or economic drivers, or have the potential to do so in the future (Adekola \& Mitchell, 2011).

Responses are actions taken by groups or individuals in society and government to prevent, compensate, ameliorate or adapt to changes in the state of the environment by seeking to control drivers or pressures through regulation, prevention, or mitigation to directly maintain or restore the state (Woodley, 2011).

While the framework has been used in Nigeria to increase understanding of threats to ecosystem services, the importance of these services to dependent communities, and potential management measures in the Niger Delta (Adekola \& Mitchell, 2011), Assessment of bio-physical indicators of desertification status in semi-arid zone of Nigeria (Ndabula, 2015), and oil spillages in the Niger Delta area (Madu et al., 2018), its application to climate change is still limited and only a few study studies exist. This study seeks to fill this void by broadening the DPSIR's application to the climate change discourse in Nigeria. It is hoped that this study will bring together information from a variety of sources in Nigeria's expanding debate on climate and environmental change.

\section{RESULTS}

\subsection{Driving forces of climate and environmental change in Nigeria}

\subsubsection{Population Dynamics}

In 2020, Nigeria's population was estimated to amount to 206 million individuals. Between 1950 and 2020, the number of people living in Nigeria regularly increased at a rate above two percent. In 2020, the population grew by 2.58 percent compared to the previous year (Population Reference Bureau, 2018).

The consumption of land resources is directly proportional to population growth, resulting in a demand for land resources that exceeds the regenerating capacity of these resources as the population grows. Nigeria currently has the world's seventh largest population, and it is the second fastest growing after India, so it is expected to overtake India as the third largest by 2050 (Population Reference Bureau, 2018). In their study showed that the mean annual pressure on land resources in Nigeria in the past five decades (1967-2017) was 9.323 hectares per capita, while the projected pressure in the next five decades (2018-2068) was 213.178 hectares per capita (Eririogu et al., 2020). This results implies that about 73.08 percent of the pressure per capita in the past five decades emanated from arable land consumption (6.813ha), while 75.91percent of the pressure is expected to emanate from fossil land in the next projected five decades due to crude oil and mineral resource exploration and exploitation. This signals a reduction in carrying capacity from 6.4091 hectares per capita (1967-2017) to 1.667 hectares per capita (2018-2068) (Eririogu et al., 2020). Moreover, the ability of land for agriculture has deteriorated as population demand on arable land has increased. According to (Olagunju, 2015), the current level of resource consumption in agriculture is resulting in a high rate of erosion, pollution, and soil deterioration.

\subsubsection{Economic Growth}

Nigeria's goal is to become the world's 20th largest economy by 2020. Because of the feedback mechanism between the environment and economic growth, there is a significant link between the two. Over the years, the environment plays a significant role in Nigeria's economic development (Bosello et al., 2018; Mereu et al., 2018). First and foremost, it generates natural resources that are used as inputs in the manufacturing process. Second, the natural environment absorbs air, water, and solid contaminants produced during the manufacturing and consuming processes (Kehinde et al., 2020).

While economic activities such as agriculture, urbanization, oil and gas exploration and refining, power generation and transmission, and transportation are important to achieving that vision, they however have a negative impact on the environment, causing environmental and climate change (Adewuyi et al., 2020). Increasing consumption of non-renewable resources, increased pollution, and the potential loss of environmental ecosystems are all examples of the environmental consequences of economic expansion Nigeria. Moreover, in 
Nigeria, growing demand for food, minerals, energy, and tourism may place further strains on the Environment. The majority of Nigeria's economic activities are primary and secondary, such as agriculture, mining, and manufacturing (Adewuyi et al., 2020). The primary sector extracts or gathers raw resources and basic foods from the soil. Agriculture (both subsistence and commercial), mining, forestry, grazing, hunting and gathering, fishing, and quarrying are all example of primary economic activity.

\subsubsection{Energy Demand and Consumption}

\section{Fossil Fuels Consumption}

Nigerian energy consumption: Energy consumption per capital for example, can be said to be an indicator that reflects annual consumption of commercial primary energy (e.g., coal, lignite, petroleum, natural gas and hydro, nuclear and geothermal electricity) in kilogr. Ams (Ansar et al., 2014; Olaniyan et al., 2018). The quest for energy will be increased to meet the demands of increasing human population. The situation will eventually lead to an increase in carbon emissions because humans, automobiles, industries, and other sectors will use more fossil fuel, resulting in higher emissions of carbon, which is a gas that is harmful to health and, among other things, causes global warming (weather modification) and air pollution (Cervigni et al., 2013). As more cars (more pollution), as seen in Lagos and Abuja, a direct effect on the water table (water scarcity), which is rapidly dropping below normal, overuse of natural resources, deforestation, desertification, urban sprawl, clearing land for residential use, and increased garbage (Cervigni et al., 2013).

\section{Biomass Energy Dynamics in Nigeria}

Biomass consumption or usage as source of energy in Nigeria has revealed an increasing trend since 1971 to 2011 as shown in Fig.5 below. Fuelwood and charcoal constitute the bulk of the biomass energy consumption in Nigeria (Ben-Iwo et al., 2016; Ohimain, 2010). More than $80 \%$ of households use fuelwood for their cooking, making it the most used form of cooking energy (Ansar et al., 2014; Naibbi \& Healey, 2013). While overdependence on fuelwood in the country has been attributed to its availability and affordability compared to the other sources of energy, the tendency towards excessive total fuelwood consumption, which is due to population growth, low technical efficiency of the traditional cooking style and the lack of adoption of other sustainable cooking methodologies (Jewitt et al., 2020). Southern parts of the country use more modern fuels (kerosene and gas) than their northern counterparts, whose cooking fuel choice is related to the erratic supply of fossil fuel in the region (Olaniyan et al., 2018). The supply of Liquefied Petroleum Gas (LPG) in the northern part of Nigeria is high in Kano state and moderate in Kaduna state. According (Onyekuru et al., 2020), despite the high supply of LPG in these states, more than $65 \%$ of their households depend on fuel wood for cooking. In contrast, Anambra, Delta and Ogun states in the south receive a low supply of. LPG. Fuelwood consumption in Nigeria is very high as shown in Fig.6 among the geo-political zones. North east is the highest (93.7\%) followed by North west (91.8) and North central (74.0\%). South west zone has the least (37.2\%) consumption of fuelwood which may be attributed to more availability of hydro-carbon fuel in the zone because of its proximity to the seaport where it is imported. while about $40 \%$ of the households used fuelwood (Adamu et al., 2020).

\subsection{State of Climate and Environment}

The state of the climate and environment is determined by observing spatiotemporal patterns or trends in forms and processes across the Nigerian landscape. Nigeria's climate is changing, as evidenced by: rising temperatures; variable rainfall; rising sea levels and flooding; drought and desertification; land degradation; more frequent extreme weather events; diminished fresh water resources; and loss of biodiversity. While there is a general decrease in rainfall in Nigeria, the coastal areas of Nigeria like Warri, Brass and Calabar are observed to be experiencing slightly increasing rainfall in recent times (Odjugo, 2005). This is clear evidence of climate change because one of the most noticeable effects of climate change is increased rainfall in most coastal areas and decreased rainfall in the continental interiors (Akpodiogaga-a \& Odjugo, 2010). According to (Odjugo, 2009), the number of rain days has decreased by $53 \%$ in north-eastern Nigeria and $14 \%$ in the Niger-Delta Coastal areas. These studies also revealed that, while the areas experiencing double rainfall are shifting southward, the short dry season (August Break) is occurring more frequently in July, as opposed to its normal occurrence in August prior to the 1970s. 
Rainfall durations and intensities have increased, causing massive runoff and flooding in many parts of Nigeria. The variability of rainfall is expected to increase further. Precipitation is expected to increase in the south, and rising sea levels are expected to exacerbate flooding and coastal land submergence. Climate change has been described as having a "considerable impact" on Nigeria (Ogunjobi et al., 2018). Temperatures in Nigeria have risen by about 1.6 degrees Celsius since the beginning of the industrial era, which is higher than the global average. Temperatures could rise by another 1.5-5 degrees Celsius by the end of the century, depending on the rate of future climate change (Niang,, et al., 2014). Despite a rise in average temperatures, there has been little research into how climate change has affected heatwaves in Nigeria. However, research indicates that heatwaves will become more common in Nigeria regardless of future warming. The number of "hot nights" in Nigeria is also expected to skyrocket in the coming decades (Akinbile et al., 2020). Hot night are those in which a region's nighttime temperatures are in the top $10 \%$. Hot nights are known to aggravate existing respiratory and other health problems and have previously been linked to increased mortality rates.

Droughts have become a regular occurrence in Nigeria since the 1980s as a result of a decrease in precipitation and an increase in temperature, and they are expected to continue in Northern Nigeria (Ogungbenro \& Morakinyo, 2014). Lake Chad and the country's other lakes are drying up and facing extinction (Pham-Duc et al., 2020). According to (Odjugo, 2005), Nigeria north of $12^{\circ} \mathrm{N}$ is under severe threat of desertification, and sand dunes are now common features of desertification in states such as Yobe, Borno, Sokoto, Jigawa, and Katsina. Advances in extreme heat, in particular, pose a threat to the many millions of Nigerians who do not have access to electricity or air conditioning. In cities, only 92 out of every 1,000 people have access to air conditioning. In rural areas, it is only 14 out of every 1,000 .

\subsubsection{State of Biodiversity}

Climate and environmental change, exacerbated by human activities and his reckless exploitation of species, continue unabated. Human activities such as bush burning, hunting, and poaching have continued to endanger the existence of wildlife in all environments (Osemeobo, 1988). As a result, many animals are on the verge of extinction and are classified as threatened or endangered. For example, Cross River Gorilla, forest and savanna elephants in Cross River and Yankari national parks, Niger-Delta red colobus monkey, African Lion in Yankari and Kainji Lake national parks, Leopard in the Gashaka Gumti national park, and African wild dog in Kainji Lake national park are among the endangered or threatened species in Nigeria (Anadu, 1987). Others include the gazelle, giraffe, and Nile crocodile, as well as Grey-headed Picartes.

\subsection{Impact Indicators of Environmental and Climate Change in Nigeria}

\subsubsection{Ecological Impacts of Climate Change}

The current $0.2 \mathrm{~m}$ sea level rise has inundated $3,400 \mathrm{~km} 2$ of Nigeria's coastal region, and if the sea level rise reaches the projected $1 \mathrm{~m}$ on or before $2100,18,400 \mathrm{~km}^{2}$ of Nigeria's coastal region may be inundated (NEST 2003). A metre rise in sea level would pose a serious threat to coastal settlements such as Bonny, Forcados, Lagos, Port Harcourt, Warri, and Calabar, among others, which are less than 10 meters above sea level. Sea-level rise causes salt-water intrusion into fresh water, as well as the invasion and destruction of mangrove ecosystems, coastal wetlands, and coastal beaches.

Drought and desertification have become more common as temperatures have risen and rainfall has decreased. Forest destruction is also a difficult challenge that exposes the environment to the more severe effects of climate change (Terdoo \& Adekola, 2014). Forests clean the air, improve water quality, preserve soils, and provide food, wood products, and medicines to the world's population, as well as habitat for many of the world's most endangered wildlife species (Adekola \& Terdoo, 2015; Adekola \& Mitchell, 2011; Anadu, 1987).

In addition to the problem of desertification, climate change is expected to increase the prevalence of pests and diseases that kill forest trees (Abiodun, Salami, et al., 2013). The study also provided explanations for the gradual extinction of forest tree species in Nigeria's various ecosystems, including the Iroko tree and oil bean in the South East, various mahogany species in the Southwest, the baobab, locust bean and gum Arabic in the 
Northwest (Osemeobo, 1988). Years of drought in Nigeria have been documented as years of invasion of locusts and pests on tender farm crops, resulting in citizen hunger. Floods destroy farm crops near river banks, resulting in poor harvests and bridge destruction, obstructing access to markets and farms (Echendu, 2020).

\section{i. Hydrology}

Climate change will alter all aspects of the hydrological cycle ranging from evaporation through precipitation, run off and discharge (Ayeni et al., 2015; Pham-Duc et al., 2020). For example, floods can also be as a result of increase in the frequency and intensity of heavy rainfall events caused by atmospheric changes (Ndabula et al., 2012b; Jidauna et al., 2016; Echendu, 2020). The global warming and decreasing rainfall together with the erratic pattern of rainfall produce a minimal recharge of groundwater resources, wells, lakes and rivers in most parts of the world especially in Africa thereby creating water crisis.

In Nigeria, many rivers have been reported to have dried up or are becoming more seasonally navigable while persistent droughts and desertification, declining frequency, amount, duration and intensity of rainfall, changes in landuse/landcover and increase in human and livestock water demand and exploitation have caused reduction of the inflow of runoff or discharge and attendant shrinking of the Lake Chad in the North East of Nigeria (Fagbohun, 2010). Lake Chad shrunk in area from 22,902 km2 in 1963 to a mere $1304 \mathrm{~km} 2$ in 2000 (Pham-Duc et al., 2020). This shows that what is left of Lake Chad in the year 2000 is just $5.7 \%$ of 1963 (P. a. O. Odjugo, 2009).

\subsubsection{Socio-Economic and Demographic Impacts}

Climate change occurring either as slow or rapid onset events is a threat to global economic development affecting various sectors of the economy (Ati et al., 2002). Impact of climate and environmental change are estimated to hurt Nigeria's economy badly, with a projected GDP losses between $2 \%$ and $11 \%$ by 2020 (Bosello et al., 2018; Cervigni et al., 2013).

\section{i. Demographic and security impacts}

Drought and desertification and the migrating sand dunes have buried large expanse of arable lands, thus reducing viable agricultural lands and crops' production (Eririogu et al., 2020). This has prompted massive emigration and resettlement of people to areas less threatened by desertification. Such emigration gives rise to social effects like loss of dignity and social values. It often results in increasing spate of communal clashes among herdsmen and farmers and such clashes (Akpodiogaga-a \& Odjugo, 2010; Ndabula et al., 2017).

The worst impact is population displacement, which may result in communal crisis. The coastal inundation and erosion with their associated population displacement are currently major environmental problems in Nembe, Eket and other coastal settlements in Bayelsa, Delta, Cross River, Rivers, and Lagos States of Nigeria (Eririogu et al., 2020). It is estimated that a metre rise in sea level will displace about 14 million people from the coastal areas of Nigeria (Sayne, 2011). Increasing number of environmental refugees has drastically increased as people are forced to leave their homes for alternative destinations with relative safety (Morland, 2017). Drought and desertification in the NE with attendant reduction in the size of the Lake Chad and other forms of land degradation have intensified conflicts among pastoralist, farmers and fishermen increasing the number of environmental refugees. Similarly oil spillage, gas flaring and land pollution from other crude oil activities have devastated ecological resources making land uncultivable and sea resources economically unviable to increase environmental refugees (Alhaji et al., 2018; Pham-Duc et al., 2020).

\section{ii. Human Health and Epidemiology}

Lake Chad had shrunk to $10 \%$ of its original size, and many rivers in Nigeria, particularly in Northern Nigeria, are in danger of drying up. Because of the scarcity of water, users will tend to congregate around the few remaining sources of water. Under such conditions, there is an increased risk of further contamination of the limited water sources, as well as the transmission of water-borne diseases such as cholera, typhoid fever, guinea worm infection, and river blindness. According to Odjugo (2000) and DeWeerdt (2007), rising temperatures will 
cause mosquitoes to migrate northward and malaria fever to spread from the tropical region to the warm temperate region, while the sporogony of the protozoa that causes malaria will shorten from 25 days at 10 degrees Celsius to 8 days at 32 degrees Celsius. Heat exhaustion, famine, water-related diseases (diarrhoea, cholera, and skin diseases), inflammatory and respiratory diseases (cough, and asthma), depression, skin cancer, and cataract will all increase as a result of climate change's excessive heat, increasing water stress, air pollution, and suppressed immune system. Confalonieri et al. (2007b) also identified the effects of climate provoking drought on health to include sudden deaths, malnutrition, infectious and respiratory diseases. Countries within the "Meningitis Belt" in semi-arid sub-Saharan Africa had experienced the highest endemic and epidemic frequency of meningococcal meningitis. The authors went on to say that the spatial distribution, intensity, and seasonality of meningococcal (epidemic) meningitis appear to be strongly linked to climate and environmental factors, especially drought.

\section{iii. Infrastructure}

Floods are low-probability, high-impact events that can overwhelm physical infrastructure and human communities, according to Confalonieri et al. (2007a). In the year 2012, Nigeria experienced major flooding that affected 21 states and resulted in the displacement of thousands, the destruction of homes, farmlands, and infrastructure - particularly roads, electric poles, and pipelines - resulting in a shortage of food production in the second half of 2012. (Okonjo-Iweala, 2013; Ujah, 2009)

\section{iv. Economy}

Agriculture: Over 70\% of Nigeria's population relies on rain-fed agriculture and fishing as their primary source of income, which accounts for more than $33 \%$ of national income (Mereu et al., 2018). A situation in which the variability in the timing and amount of rainfall poses a high risk to the food production system (Mereu et al., 2018). Crops account for nearly 94 percent of the agricultural sector in Nigeria, and some areas are already experiencing a 20 percent reduction in the length of growing days (Ati et al., 2002). Temperature increases reduce the growth rates of maize, guinea corn, millet, and rice. Warming trends also make root crops and vegetables more difficult to store for those who do not have access to refrigerators. Increasing variations in the timing and amount of rainfall will have a negative impact on agriculture. Water scarcity may also reduce crop and livestock production, necessitating imports (Akinbile et al., 2020). The impact of climate change on agriculture can be seen in the southern part of Nigeria through the effects of gully erosion on land use. Gully erosion has resulted in the loss of a significant amount of arable land in the states of Anambra, Enugu, Ebonyi, and Kogi. Sometimes the effects of erosion take the form of leaching, in which agricultural lands are devastated, rendering the land unproductive and resulting in a poor harvest (Abiodun, Salami, et al., 2013).

Drought caused by climate change, particularly in the eastern parts, has resulted in environmental conditions such as decreased pasture, soil, and surface inflow of water, particularly to Lake Chad, causing it to shrink in the region. This has resulted in overpopulation of livestock in the Chad basin, as well as a southward shift, complicating farmer-fisherman-herder conflicts (Bashir \& Kyung-Sook, 2018). Empirical studies (Ubani Onyejeke, 2013; Ojimba and Iyagba, 2012) have found that gas flaring and crude oil spillages and pollution have a negative impact on agricultural yield, farmland loss, and the degradation of fish and other aquatic resources in the Niger Delta region (Adekola \& Mitchell, 2011). Aside from floods and drought, there are other types of extreme weather events, such as hailstorms/hailstones that accompany heavy rains, causing widespread destruction of rural farmers' houses and agricultural crops, particularly in northern Nigeria (Ibrahim, 2012; Abubakar, 2013). Furthermore, severe floods have destroyed vast swaths of fertile floodplain farmlands. Increased rainfall in Southern Nigeria, combined with irregular rainfall events, has also caused flooding, which has harmed mining operations as well as offshore drilling in the region (Adesina \& Odekunle, 2011).

Manufacturing: According to Yahaya et al. (2011), the effect of global warming on climate-vulnerable sectors of the economy such as agriculture and coastal resources that provide inputs for industry has threatened infant industries as well as small and medium-sized businesses (Mereu et al., 2018; Olaniran, 1991). According to the authors, this development will have a negative impact on the country's GDP due to a lack of access to manufacturing inputs. Similarly, the Manufacturing Sector suffered significant losses due to flooding, impeding 
its ability to meet production targets. This is due to the sector's reliance on agricultural

products as inputs, which are vulnerable to climate change (Nachmany et al., 2015).

Tourism: According to Anadu (1987) and (Osemeobo, 1988), forests continue to be a haven for wildlife, and if the forests disappear, the wildlife does as well. This makes tourist attractions in Nigeria more vulnerable to climate change, resulting in a loss of patronage and revenue for the tourism industry.

Food Insecurity: More than 800 million people in tropical and sub-tropical countries are currently food insecure. This is as a result of increased crop failure and loss of livestock. Climate change is expected to affect human health and livelihoods. Crops occupy nearly 94 percent of the agricultural sector in Nigeria. Some areas are already experiencing loss in the length of growing days by 20 percent (Ati et al., 2002).

Pests and crop diseases can also spring up in response to climatic variations which may hamper food storage. The extreme weather events like storms, heavy winds and floods may ravage farmlands, leading to crop failure, and food shortage (Echendu, 2020). The challenge of food insecurity from climate change experience is also expected to affect human health, livelihoods, and people's purchasing power at household level across Nigeria (Oladipo, 2010).

Pests and crop diseases can also spring up in response to climatic variations which may hamper food storage. The extreme weather events like storms, heavy winds and floods may ravage farmlands, leading to crop failure, food shortage and food shortage (Liu et al., 2008; Oort \& Zwart, 2018). The challenge of food insecurity from Climate change experience is also expected to affected human health, livelihoods, people's purchasing power at household level. According to (Milos \& Sani, 2017) the warming trend also hinders livestock production with reduction in animal weight and diary yield. Desertification and reduction in Lake Chad water levels are likely to cause food shortage in the Northern Sahel region, which accounts for 26.6 percent of Nigeria's land area. Agricultural practice in Southern Nigeria is also affected by climate change because of low elevation structure of the area, which subjected it to salt water intrusion as the sea level rises (BNRCC (Building Nigeria's Response to Climate Change Project), 2011).

v. Impact on Energy Generation and Supply in Nigeria

Energy services are necessary inputs for every nation's development and growth. And also the fuel driving the engine of growth and sustainability development is a nation's access to reliable and adequate energy (Ben-Iwo et al., 2016). Nigeria has an abundant supply of energy sources as it's endowed with thermal, hydro, solar, oil resources and yet still described as an energy poor country (Olaniyan et al., 2018). Nigeria as a country is highly vulnerable to the impact of climate change because its economy is mainly dependent on income generated from the production, processing, export and/or consumption of fossil fuels and associated energy-intensive products (Sayne, 2011).

Nigeria will be increasingly be affected by climate change in trends, increasing variability, greater extremes and large inter-annual variations in climate parameters in some regions (Akpodiogaga-a \& Odjugo, 2010). Climate change is also expected to negatively impact the already limited electrical power supply through impacts on hydroelectric and thermal generation coupled with service interruptions is also expected to result from damage to transmission lines and substation equipment impacted by sea level rise, flash floods and other extreme weather events (Oguntunde et al., 2011).

\subsection{Responses}

4.4.1 Nigeria's response to climate change includes strategies for mitigation, adaptation, and resilience building.

Mitigation: responses are aimed at reducing GHG emissions from the four key sectors of the economy that are responsible for them (Table 1). In doing so, the Federal Government of Nigeria pledged as its Intended Nationally Determined Contribution (INDC) to climate change mitigation at the Paris climate summit in 
December 2015 to implement policies and strategies that facilitate a $20 \%$ unconditional and $40 \%$ conditional reduction in GHG emissions by 2030. (Nachmany et al., 2015). To that end, the Nigerian government intends to work on: (i) ending gas flaring; (ii) constructing efficient gas power plants; (iii) reducing transmission losses by improving the electricity grid; (iv) increasing off-grid solar PV by investing in renewable energy; (v) increasing economy-wide energy efficiency; (vi) promoting climate smart agriculture and reforestation; and (vii) promoting climate smart agriculture and reforestation. Previous efforts at reforestation in Nigeria were among these strategies (Osemeobo, 1988). While reforestation efforts have the potential to sequester $\mathrm{CO} 2$, thus mitigating climate change, such efforts have failed in Nigeria due to a lack of widespread conservation agricultural practices, unsustainable logging, and an increasing population of households relying on fuelwood to meet their daily energy needs (Boahene, 1998; Osemeobo, 1988). Renewable energy, such as the construction of solar panels, is another important aspect that has recently gained government attention. However, on a grand scale, this is insignificant.

Adaptation and resilience: Table 1 highlights a number of overlapping responses that various sectors of the Nigerian economy could employ in the face of the aforementioned adverse effects of climate change (Sayne, 2011). Depending on the level of costs or investments required, these responses are classified as soft or hard, structural or non-structural (Bosello, 2018). Soft or non-structural adaptation strategies frequently aim to help actors cope with the effects of climate change. Crop and livestock farmers, for example, commonly use soft adaptive practices such as shifting the sowing/planting date and planting drought-resistant crops and livestock feeds (Oloruntade et al., 2017). In practice, these soft practices are frequently less expensive, and no expert training is required to employ them, so they are widely used by resourced poor actors (e.g., small landholders) across Nigeria's eco-climatic belts.

On the other hand, there are a number of hard or structural adaptation strategies available, such as increasing irrigated crop area and using inorganic soil fertilizers, among others (Table 1) (Adesina \& Odekunle, 3011). The goals of these strategies extend beyond the formal goal of constructing a coping mechanism to the goal of constructing resilience in the various systems and sectors of the economy. Diversification, early warning systems, risk management, and human development and capacity building are examples of resilience building strategies. One significant benefit of diversification is that it creates a backup or buffer that helps spread risks. Thus, in the agricultural sector, actors can shift from crop to livestock and vice versa, or to other sources of income (e.g., daily paid work). While new

infrastructure can be built across various sectors (e.g., energy, communication, and transportation) as a backup in the event that existing infrastructure is disrupted due to the adverse effects of climate change (e.g. flooding, rainstorm, sea level rise, droughts) (Bosello et al., 2018).

\section{CONCLUSION}

This review synthesised evidence on the impact of climate change in Nigeria (geographic, sectoral, demographic and security impacts) and responses to address it (i.e. climate change mitigation and adaptation, adaptive capacity and capacity development). If the above-mentioned mitigation, adaptation, and resilience-building strategies are not implemented, the effects of climate change on the Nigerian economy are likely to worsen. This could result in GDP losses ranging from $6 \%$ to $30 \%$ by 2050 , corresponding to N15 trillion (US\$100 billion) and N69 trillion (US\$460 billion) in monetary terms, respectively (Bosello et al., 2018; Cervigni et al., 2013; Mereu et al., 2018; Nachmany et al., 2015).

Consequently, the review advocates for the rapid development of climate and environmental change policies in order to reposition the Nigerian environment for recovery and to avoid future over-exploitation of natural capital, which will eventually lead to the complete breakdown and shutdown of ecosystem functions and services critical 
to supporting livelihoods across the country. The review also emphasizes the importance of adaptation planning and inter-sectoral and inter-actor collaborative actions for resilience building in order to strengthen the Nigerian economy and improve the capacities and livelihoods of Nigerians in managing and mitigating the effects of climate and environmental change across all agro-ecological regions.

\section{REFERENCES}

Abiodun, B. J., Lawal, K. A., Salami, A. T., \& Abatan, A. A. (2013). Potential influences of global warming on future climate and extreme events in Nigeria. Regional Environmental Change, 13, 3, 477-491. https://doi.org/10.1007/s10113-012-0381-7

Abiodun, B. ,J., Salami, A. T., Matthew, O. J., \& Odedokun, S. (2013). Potential impacts of afforestation on climate change and extreme events in Nigeria. Climate Dynamics, 41, 2, $277-293$. https://doi.org/10.1007/s00382-012-1523-9

Adamu, M. B., Adamu, H., Ade, S. M., \& Akeh, G. I. (2020). Household Energy Consumption in Nigeria: A Review on the Applicability of the Energy Ladder Model. Journal of Applied Sciences and Environmental Management, 24, 2, 237-244. https://doi.org/10.4314/jasem.v24i2.7

Adekola, O., \& Fanen, T. (2015). Integrating Ecosystem Services Approach in Achieving Development Goals: The Role of the Geographer. 10.

Adekola, O., \& Mitchell, G. (2011). The Niger Delta wetlands: Threats to ecosystem services, their importance to dependent communities and possible management

measures. International Journal of Biodiversity Science, Ecosystem Services \& Management, 7, 1, 50-68. https://doi.org/10.1080/21513732.2011.603138

Adesina, F. A., \& Odekunle, T. O. (n.d.). Climate Change and Adaptation in Nigeria: Some Background to Nigeria's Response-III. 9.

Adewuyi, O. B., Kiptoo, M. K., Afolayan, A. F., Amara, T., Alawode, O. I., \& Senjyu, T. (2020). Challenges and prospects of Nigeria's sustainable energy transition with lessons from other countries' experiences. Energy Reports, 6, 993-1009. https://doi.org/10.1016/j.egyr.2020.04.022

Akinbile, C. O., Ogunmola, O. O., Abolude, A. T., \& Akande, S. O. (2020). Trends and spatial analysis of temperature and rainfall patterns on rice yields in Nigeria. Atmospheric Science Letters, 21, 3, 944. https://doi.org/10.1002/asl.944

Akpodiogaga-a, P., \& Odjugo, O. (2010). General Overview of Climate Change Impacts in Nigeria. Journal of Human Ecology, 29, 1, 47-55. https://doi.org/10.1080/09709274.2010.11906248

Alhaji, N. B., Babalobi, O. O., Wungak, Y., \& Ularamu, H. G. (2018). Participatory survey of Rift Valley fever in nomadic pastoral communities of North-central Nigeria: The associated risk pathways and factors. PLOS Neglected Tropical Diseases, 12, 10, e0006858. https://doi.org/10.1371/journal.pntd.0006858

Anadu, P. A. (1987). Wildlife conservation in Nigeria: Problems and strategies. The Environmentalist, 7, 3, 211220. https://doi.org/10.1007/BF02233594

Ansar, A., Flyvbjerg, B., Budzier, A., \& Lunn, D. (2014). Should we build more large dams? The actual costs of hydropower megaproject development. Energy Policy, 69, $43-56$. https://doi.org/10.1016/j.enpol.2013.10.069

Ati, O. F., Stigter, C. J., \& Oladipo, E. O. (2002). A comparison of methods to determine the onset of the growing season in northern Nigeria. International Journal of Climatology, 22, 6, 731-742. https://doi.org/10.1002/joc.712

Ayanlade, A., Radeny, M., Morton, J. F., \& Muchaba, T. (2018). Rainfall variability and drought characteristics in two agro-climatic zones: An assessment of climate change challenges in Africa. Science of The Total Environment, 630, 728-737. https://doi.org/10.1016/j.scitotenv.2018.02.196

Ayeni, A. O., Kapangaziwiri, E., Soneye, A. S. O., \& Engelbrecht, F. A. (2015). Assessing the impact of global changes on the surface water resources of southwestern Nigeria. Hydrological Sciences Journal, 6, 11, 1956-1971. https://doi.org/10.1080/02626667.2014.993645

Bashir, A., \& Kyung-Sook, C. (2018). A review of the evaluation of irrigation practice in Nigeria: Past, present and future prospects. African Journal of Agricultural Research, 13, 40, 2087-2097. https://doi.org/10.5897/AJAR2018.13403

Ben-Iwo, J., Manovic, V., \& Longhurst, P. (2016). Biomass resources and biofuels potential for the production of transportation fuels in Nigeria. Renewable and

Sustainable Energy Reviews, 63, 172-192. https://doi.org/10.1016/j.rser.2016.05.050 
Bidone, E. D., \& Lacerda, L. D. (2004). The use of DPSIR framework to evaluate sustainability in coastal areas. Case study: Guanabara Bay basin, Rio de Janeiro, Brazil. Regional Environmental Change, 4, 1, 5-16. https://doi.org/10.1007/s10113-003-0059-2

BNRCC (Building Nigeria's Response to Climate Change Project). (2011). NATIONAL ADAPTATION STRATEGY AND PLAN OF ACTION ON CLIMATE CHANGE FOR NIGERIA (NASPA-CCN). http://csdevnet.org/wp-content/uploads/NATIONAL-ADAPTATION-STRATEGY-AND-PLAN-OFACTION.pdf

Boahene, K. (1998). THE CHALLENGE OF DEFORESTATION IN TROPICAL AFRICA: REFLECTIONS ON ITS PRINCIPAL CAUSES , CONSEQUENCES AND SOLUTIONS.

Bosello, F., Campagnolo, L., Cervigni, R., \& Eboli, F. (2018). Climate Change and Adaptation: The Case of Nigerian Agriculture. Environmental and Resource Economics, 69, 4, 787-810. https://doi.org/10.1007/s10640-016-0105-4

Cervigni, R., Valentini, R., \& Santini, M. (2013). Toward Climate-Resilient Development in Nigeria (Directions in development.). World Bank.

Cervigni, R., \& World Bank (Eds.). (2013). Assessing Low carbon-development in Nigeria: An analysis of four sectors. The World Bank.

Domínguez-Gómez, J. A. (2016). Four conceptual issues to consider in integrating social and environmental factors in risk and impact assessments. Environmental Impact Assessment Review, 56, 113-119. https://doi.org/10.1016/j.eiar.2015.09.009

Echendu, A. J. (2020). The impact of flooding on Nigeria's sustainable development goals (SDGs). Ecosystem Health and Sustainability, 6, 1, 1791735. https://doi.org/10.1080/20964129.2020.1791735

Eririogu, H. I., Echebiri, R. N., \& Ebukiba, E. S. (2020). Population Pressure on Land Resources in Nigeria: The Past and Projected Outcome. Journal of Energy Research and Reviews, 20-34. https://doi.org/10.9734/jenrr/2020/v4i230122

Fanen, T., \& Olalekan, A. (2014). Assessing the role of climate-smart agriculture in combating climate change, desertification and improving rural livelihood in Northern Nigeria. African Journal of Agricultural Research, 9, 15, 1180-1191. https://doi.org/10.5897/AJAR2013.7665

Jalloh, A. (Ed.). (2013). West African agriculture and climate change: A comprehensive analysis (1st ed). International Food Policy Research Institute.

Jewitt, S., Atagher, P., \& Clifford, M. (2020). "We cannot stop cooking": Stove stacking, seasonality and the risky practices of household cookstove transitions in Nigeria. Energy Research \& Social Science, 61, 101340. https://doi.org/10.1016/j.erss.2019.101340

Jidauna, G.G., Joseph, N.N., Ndabula, C., \& Oyatayo, K.T. (2019). Assessment of landuse landcover changes in Dutsin-Ma Local Government Area of Katsina State, Nigeria (1988-2014). Journal of Environmental Sciences (JOES), 19, I \& II: 133-145.

Jidauna G. G., Ndabula C., Saidu B. J., Oyatayo T. K., Dahiru M. K., Dabi D. D., \& Oche C. Y. (2016). Adaptation and Mitigation to Water Stress in Safana Local Government Headquarters of Katsina State, Nigeria. International Journal of Natural Resource Ecology and Management. 1, 3, 99-106. doi: 10.11648/j.ijnrem.20160103.15 http:/www.sciencepublishinggroup.com/j/ijnrem.

Kehinde, O., Ramonu, O. J., Babaremu, K. O., \& Justin, L. D. (2020). Plastic wastes: Environmental hazard and instrument for wealth creation in Nigeria. Heliyon, 6(10). https://doi.org/10.1016/j.heliyon.2020.e05131

Liu, J., Fritz, S., van Wesenbeeck, C. F. A., Fuchs, M., You, L., Obersteiner, M., \& Yang, H. (2008). A spatially explicit assessment of current and future hotspots of hunger in Sub-Saharan Africa in the context of global change. Global and Planetary Change, 64, 3-4, 222-235. https://doi.org/10.1016/j.gloplacha.2008.09.007

Mereu, V., Santini, M., Cervigni, R., Augeard, B., Bosello, F., Scoccimarro, E., Spano, D., \& Valentini, R. (2018) Robust Decision Making for a Climate-Resilient Development of the Agricultural Sector in Nigeria. In L. Lipper, N. McCarthy, D. Zilberman, S. Asfaw, \& G. Branca (Eds.), Climate Smart Agriculture: Building Resilience to Climate Change, pp. 277-306. Springer International Publishing. https://doi.org/10.1007/978-3-319-61194-5_13

Milos, C., \& Sani, M. (n.d.). AGRICULTURE, MARKETS, MIGRANTS AND THE URBAN SYSTEM IN KATSINA STATE. 104.

Morland, A. (2017, June 22). Africa: Fact File - Climate Change, Food Security, and Adaptation. IRIN. https://allafrica.com/stories/201706220941.html

Nachmany, M., Fankhauser, S., Davidová, J., Kingsmill, N., Landesman, T., Roppongi, H., Schleifer, P., Setzer, J., Sharman, A., Singleton, C. S., Sundaresan, J., \& Townshend, T. (2015). CLIMATE CHANGE 
LEGISLATION IN Nigeria AN EXCERPT FROM The 2015 Global Climate Legislation Study- A Review of Climate Change Legislation in 99 Countries. The Grantham Research Institute on Climate Change and the Environment, The Global Legislators Organisation (GLOBE), and The Inter-Parlamentary Union (IPU). http://www.lse.ac.uk/GranthamInstitute/wp-content/uploads/2015/05/NIGERIA.pdf

Naibbi, A. I., \& Healey, R. G. (2013). Northern Nigeria's Dependence on Fuelwood: Insights from Nationwide Cooking Fuel Distribution Data. International Journal of Humanities and Social Science, 3(17), 14.

Ndabula, C., Jidauna, G.G., Oyatayo, K., Averik, P.D., \& Iguisi, E.O., (2012a). Analysis of Urban Floodplain Encroachment: Strategic Approach to Flood and Floodplain Management in Kaduna Metropolis. Journal of Geography and Geology,.4.1, 170-182.

Ndabula, C., Jidauna, G.G., Averik, P.D., Dewingong, L.C., \& Iguisi, E.O. (2012b). A GIS Model Approach for Integrated Floodplain Management and Sustainable Urban Development in Kaduna Metropolis. International Journal of Innovation in Management Science, 4, 1, 48-57.

Ndabula, C., Jidauna, G G., Averik, P.D., Oyatayo, T.K., Abaje, I.B., \& Ali, A.Y (2014). Characterization of Sprawling in Kaduna Metropolitan Area. American Journal of Environmental Protection. 3, 3, 131-137.

Ndabula, C., Averik P. D., Jidauna G.G., Abaje I., Oyatayo T. K., \& Iguisi., E.O. (2013) . Analysis of the Spatio-Temporal Dynamics of Landuse/ Landcover Stuctures in the Kaduna Innercore City Region, Nigeria, American Journal of Environmental Protection, 1, 4, 112-119.

Ndabula, C. (2015). Assessment bio-physical indicators of desertification status in the semi-arid zone of Nigeria. A Ph.D Thesis in the Department of Geography, Ahmadu Bello University Zaria, Nigeria (Unpublished).

Ndabula, C., Iguisi, E.O., Jidauna, G.G.,Oyatayo, K., \& Nyomo, D.J. (2017). Analysis of HydroGeomorphic Sensitivity Areas and Desertification in part of Borno-Yobe Semi-arid Zone of Nigeria, FUDMA Journal of Science, 1,.1, 143-160.

Niang, I., Ruppel, O. C., Abdrabo, M. A., Essel, A., Lennard, C., Padgham, J., \& Urquhart, P. (2014). Chapter 22 Africa. In: Climate Change 2014: Impacts, Adaptation, and Vulnerability. Part B: Regional Aspects. Contribution of Working Group II to the Fifth Assessment Report of the Intergovernmental Panel on Climate Change. In Climate Change 2014: Impacts, Adaptation, and Vulnerability (e [Barros, V.R., C.B. Field, D.J. Dokken, M.D. Mastrandrea, K.J. Mach, T.E. Bilir, M. Chatterjee, K.L. Ebi, Y.O. Estrada, R.C. Genova, B. Girma, E.S. Kissel, A.N. Levy, S. MacCracken, P.R. Mastrandrea, and L.L.White, pp. 1199-1265.). Cambridge University Press, Cambridge. https://www.researchgate.net/publication/309475977_Chapter_22_Africa_In_Climate_Change_2014_I mpacts_Adaptation_and_Vulnerability_Part_B_Regional_Aspects_Contribution_of_Working_Group_II to_the_Fifth_Assessment_Report_of_the_Intergovernmental_Panel_on

Odjugo, P. A. (2005). An analysis of rainfall patterns in Nigeria. Global Journal of Environmental Sciences, 4(2), 139-145. https://doi.org/10.4314/gjes.v4i2.2455

Odjugo, P. a. O. (2009). The Impact Of Climate Change On Water Resources: Global And Nigerian Analysis. FUTY Journal of the Environment, 4(1), 59-77. https://doi.org/10.4314/fje.v4i1.48005

Ogungbenro, S. B., \& Morakinyo, T. E. (2014). Rainfall distribution and change detection across climatic zones in Nigeria. Weather and Climate Extremes, 5-6, 1-6. https://doi.org/10.1016/j.wace.2014.10.002

Ogunjobi, K. O., Adamu, Y., Akinsanola, A. A., \& Orimoloye, I. R. (2018). Spatio-temporal analysis of land use dynamics and its potential indications on land

surface temperature in Sokoto Metropolis, Nigeria. Royal Society Open Science, 5(12). https://doi.org/10.1098/rsos.180661

Oguntunde, P. G., Abiodun, B. J., \& Lischeid, G. (2011). Rainfall trends in Nigeria, 1901-2000. Journal of Hydrology, 411(3), 207-218. https://doi.org/10.1016/j.jhydrol.2011.09.037

Ohimain, E. I. (2010). Emerging bio-ethanol projects in Nigeria: Their opportunities and challenges. Energy Policy, 38(11), 7161-7168. https://doi.org/10.1016/j.enpol.2010.07.038

Oladipo, E. O. (1993). A comprehensive approach to drought and desertification in Northern Nigeria. Natural Hazards, 8(3), 235-261. https://doi.org/10.1007/BF00690910

Oladipo, P. E. O. (n.d.). TOWARDS ENHANCING THE ADAPTIVE CAPACITY OF NIGERIA: 44.

Olagunju, T. E. (2015). Drought, desertification and the Nigerian environment: A review. Journal of Ecology and The Natural Environment, 7(7), 196-209. https://doi.org/10.5897/JENE2015.0523

Olaniran, O. J. (1991). Evidence of climatic change in Nigeria based on annual series of rainfall of different daily amounts, 1919-1985. Climatic Change, 19(3), 319-340. https://doi.org/10.1007/BF00140169

Olaniyan, K., McLellan, B. C., Ogata, S., \& Tezuka, T. (2018). Estimating Residential Electricity Consumption 
in Nigeria to Support Energy Transitions. Sustainability, $10(5), \quad 1440$. https://doi.org/10.3390/su10051440

Oloruntade, A. J., Mohammad, T. A., Ghazali, A. H., \& Wayayok, A. (2017). Analysis of meteorological and hydrological droughts in the Niger-South Basin, Nigeria. Global and Planetary Change, 155, 225-233. https://doi.org/10.1016/j.gloplacha.2017.05.002

Onyekuru, N. A., Ifejirika, C. A., Onuigbo, D. M., Mebo, R. A., \& Eboh, E. C. (2020). Factors affecting households' choice of cooking energy in Enugu State, Nigeria. Agro-Science, 19, 4, 6-13. https://doi.org/10.4314/as.v19i4.2

Oort, P. A. J. van, \& Zwart, S. J. (2018). Impacts of climate change on rice production in Africa and causes of simulated yield changes. Global Change Biology, 24, 3, 1029-1045. https://doi.org/10.1111/gcb.13967

Osemeobo, G. J. (1988). The Human Causes of Forest Depletion in Nigeria. Environmental Conservation, 15, 1, 17-28. https://doi.org/10.1017/S0376892900028411

Pham-Duc, B., Sylvestre, F., Papa, F., Frappart, F., Bouchez, C., \& Crétaux, J.-F. (2020). The Lake Chad hydrology under current climate change. Scientific Reports, 10(1), 5498. https://doi.org/10.1038/s41598-020-62417-w

Population Reference Bureau. (2018). World Population Data Sheet. https://www.prb.org/wpcontent/uploads/2018/08/2018_WPDS.pdf

Rockström, J., Steffen, W., Noone, K., Persson, Å., Chapin, F. S. I., Lambin, E., Lenton, T., Scheffer, M., Folke, C., Schellnhuber, H. J., Nykvist, B., de Wit, C., Hughes, T., van der Leeuw, S., Rodhe, H., Sörlin, S., Snyder, P., Costanza, R., Svedin, U., ... Foley, J. (2009). Planetary Boundaries: Exploring the Safe Operating Space for Humanity. Ecology and Society, 14(2). https://doi.org/10.5751/ES-03180-140232

Sayne, A. (2011). Climate Change Adaptation and Conflict in Nigeria (Special Report No. 274,. 16. United State Institute of Peace.

Steffen, W., Persson, Å., Deutsch, L., Zalasiewicz, J., Williams, M., Richardson, K., Crumley, C., Crutzen, P., Folke, C., Gordon, L., Molina, M., Ramanathan, V., Rockström, J., Scheffer, M., Schellnhuber, H. J., \& Svedin, U. (2011). The Anthropocene: From Global Change to Planetary Stewardship. Ambio, 40, 7 , 739-761. https://doi.org/10.1007/s13280-011-0185-x

Woodley, E. (2011). Building Nigeria's Response to Climate Change: Pilot Projects for Community-Based Adaptation in Nigeria. In W. Leal Filho (Ed.), Experiences of Climate Change Adaptation in Africa (pp. 297-315). Springer Berlin Heidelberg. https://doi.org/10.1007/978-3-642-22315-0_19. 
Table 1: Nigeria's possible climate change mitigation and adaptation and resilience building strategies

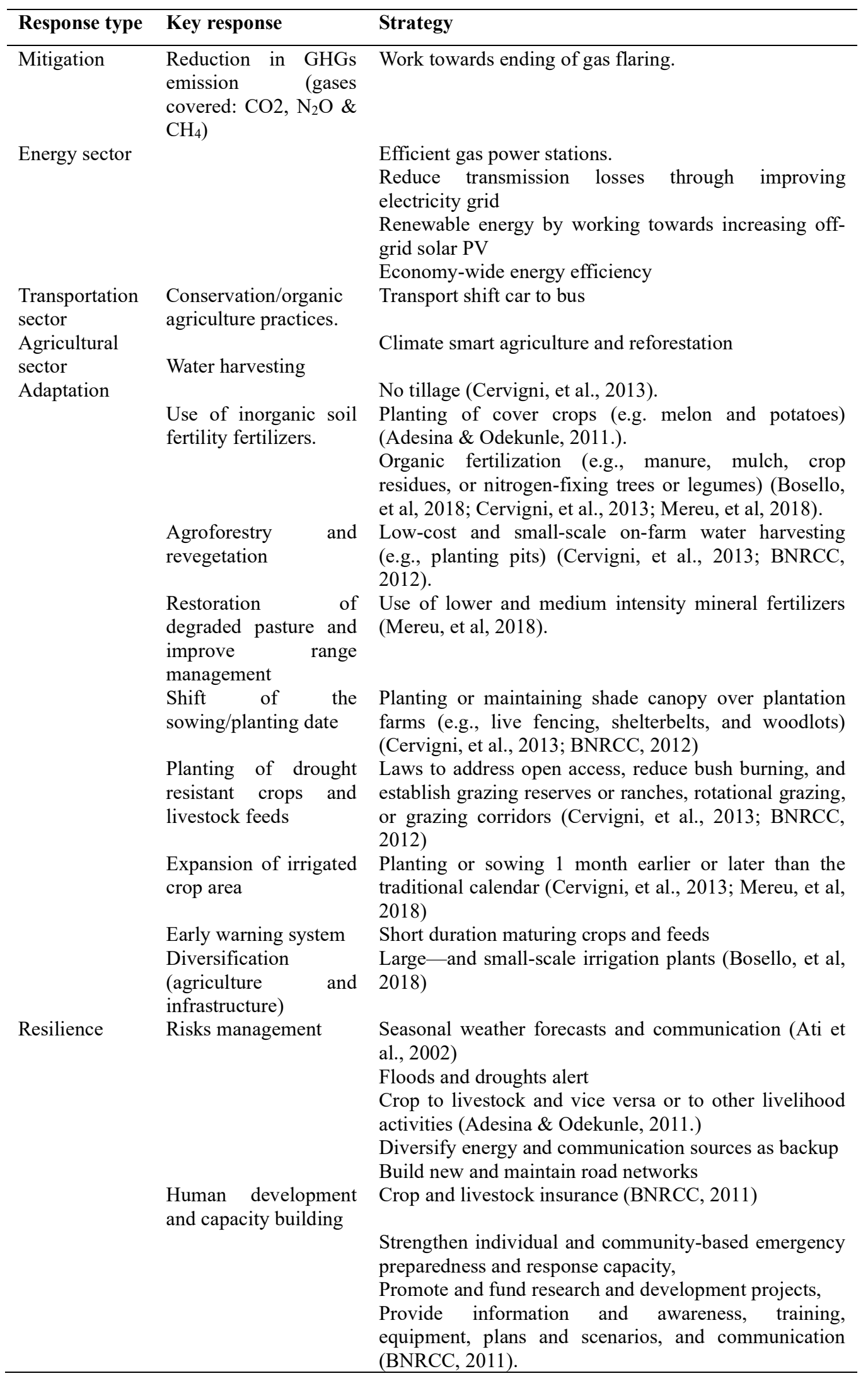




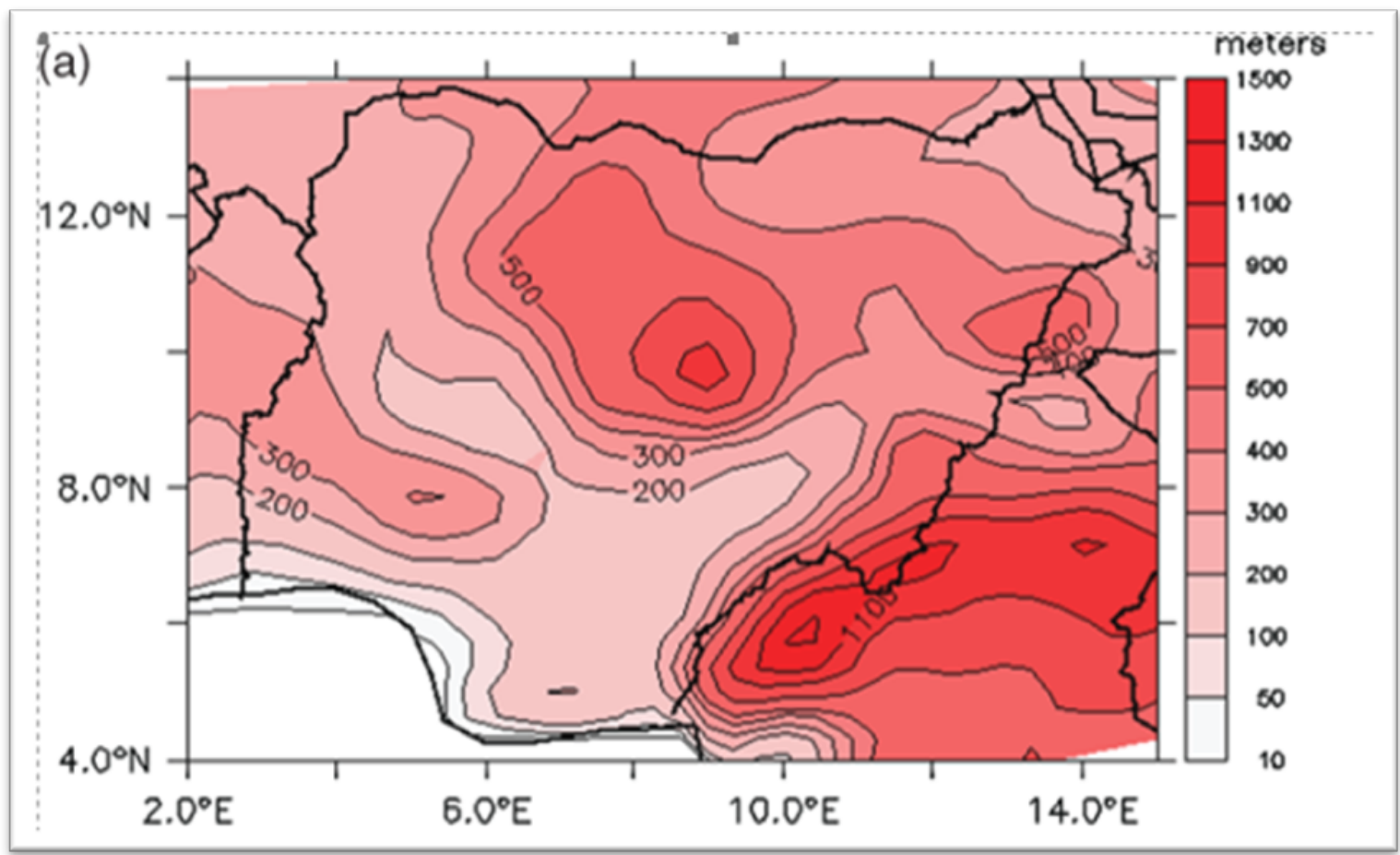

Figure 1: Nigerian Topography (adapted from Abiodun, Lawal, Salami, \& Abatan, 2013).

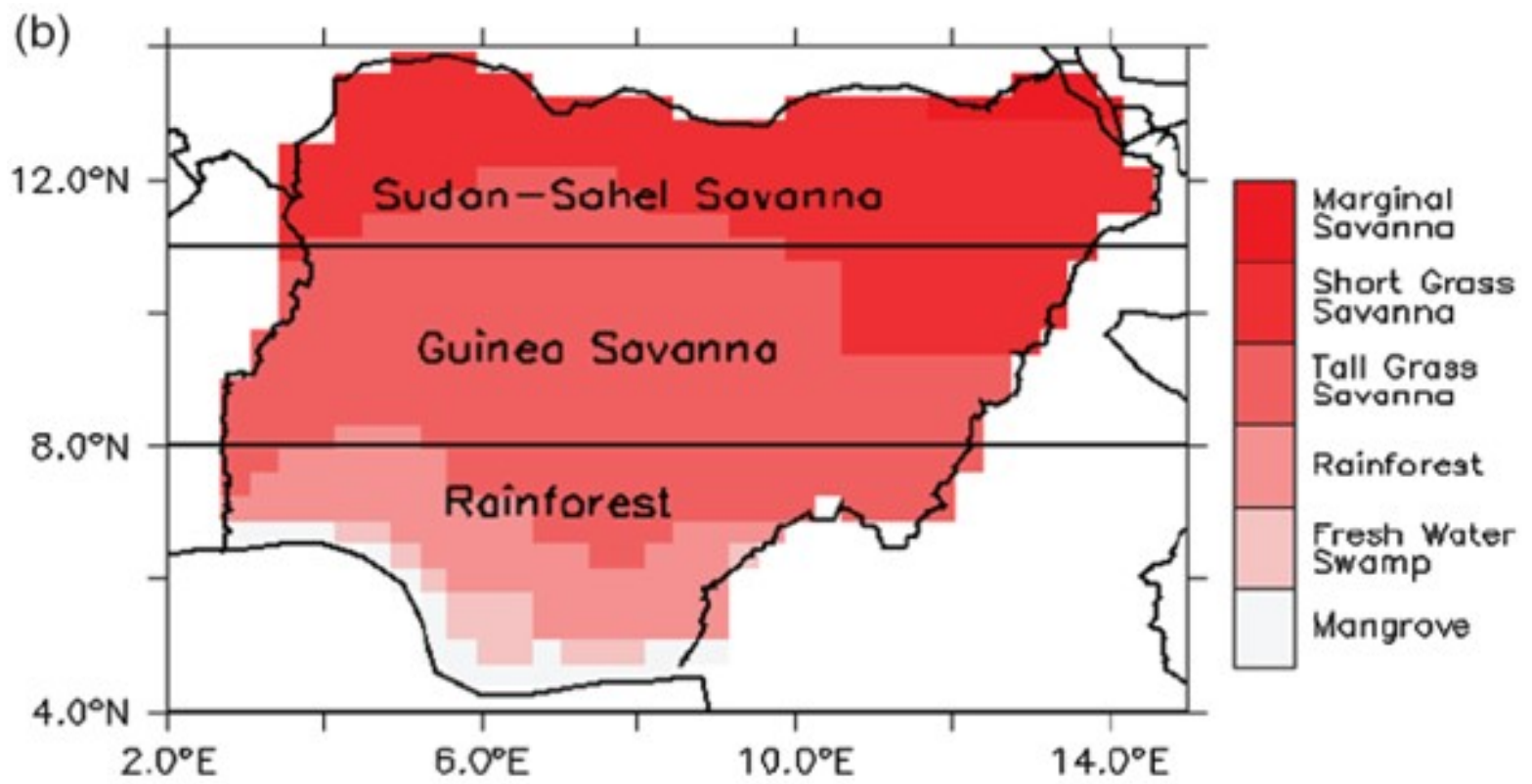

Figure 2: Nigerian Ecological Zones (adapted from Abiodun, Lawal, Salami, \& Abatan, 2013). 


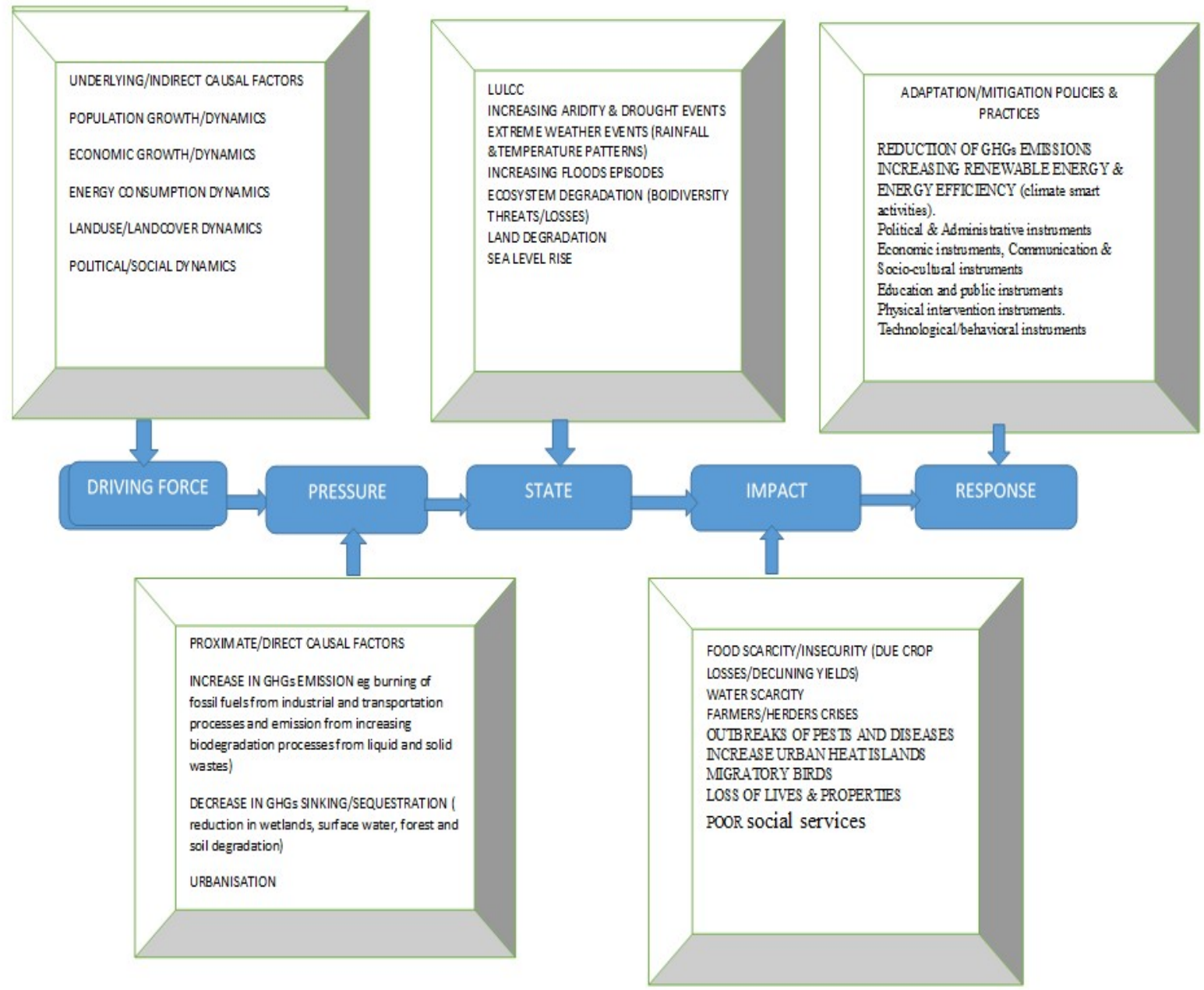

Figure 3: DPSIR Framework for climate and environmental change in Nigeria 


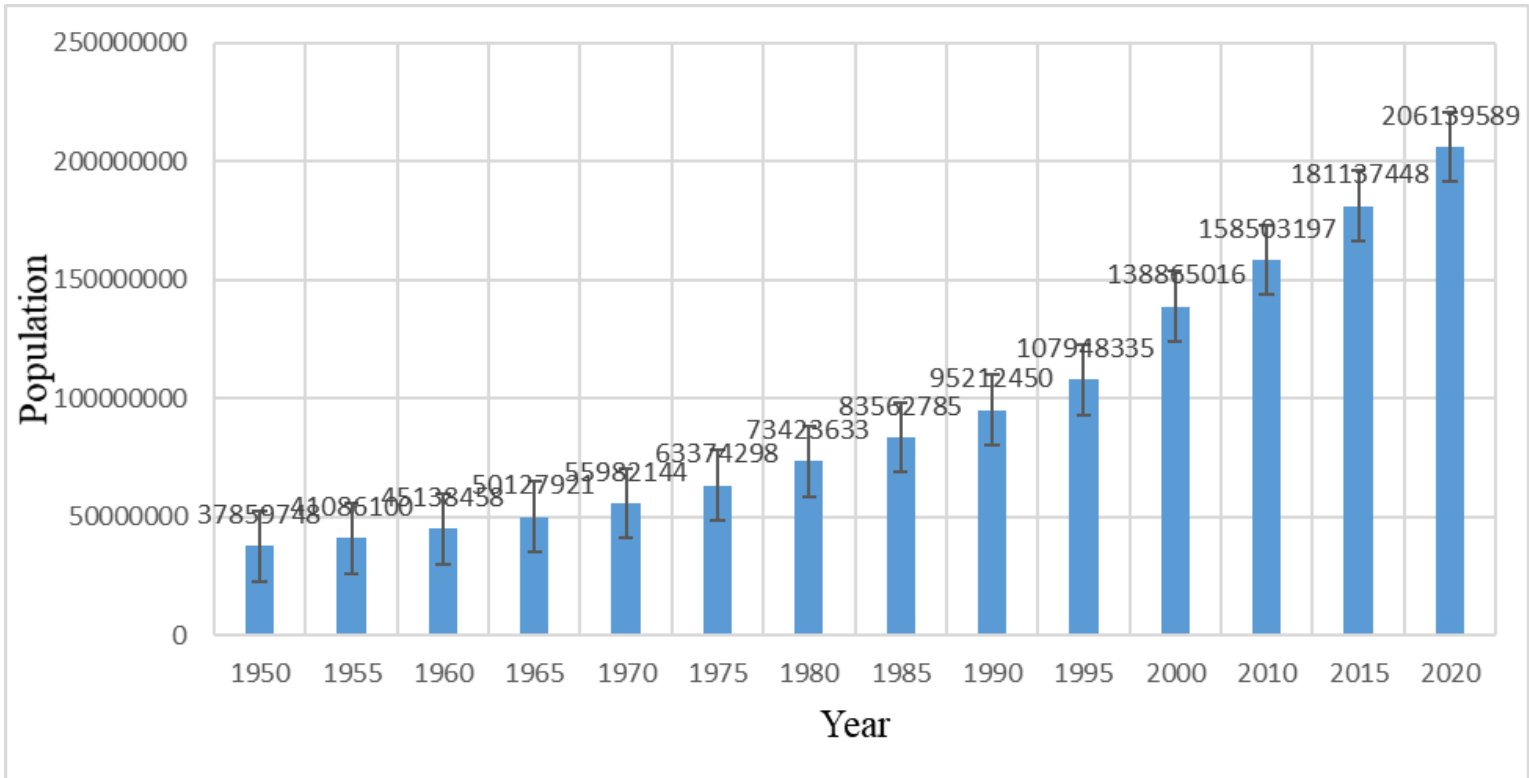

Figure 4: Trend of Population Growth in Nigeria (1950-2020) (Population Reference Bureau, 2018)

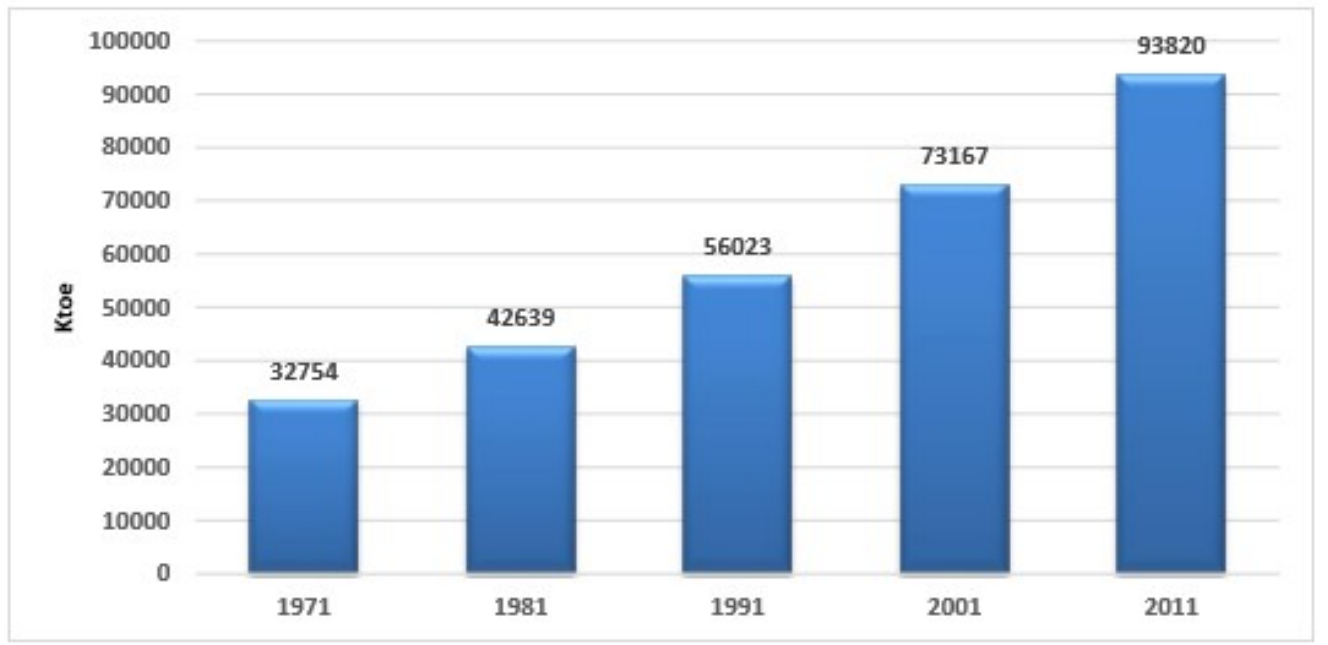

Figure 5: Trends in Biomass Consumption in Thousands Metric Tons (IEA, 2013) 


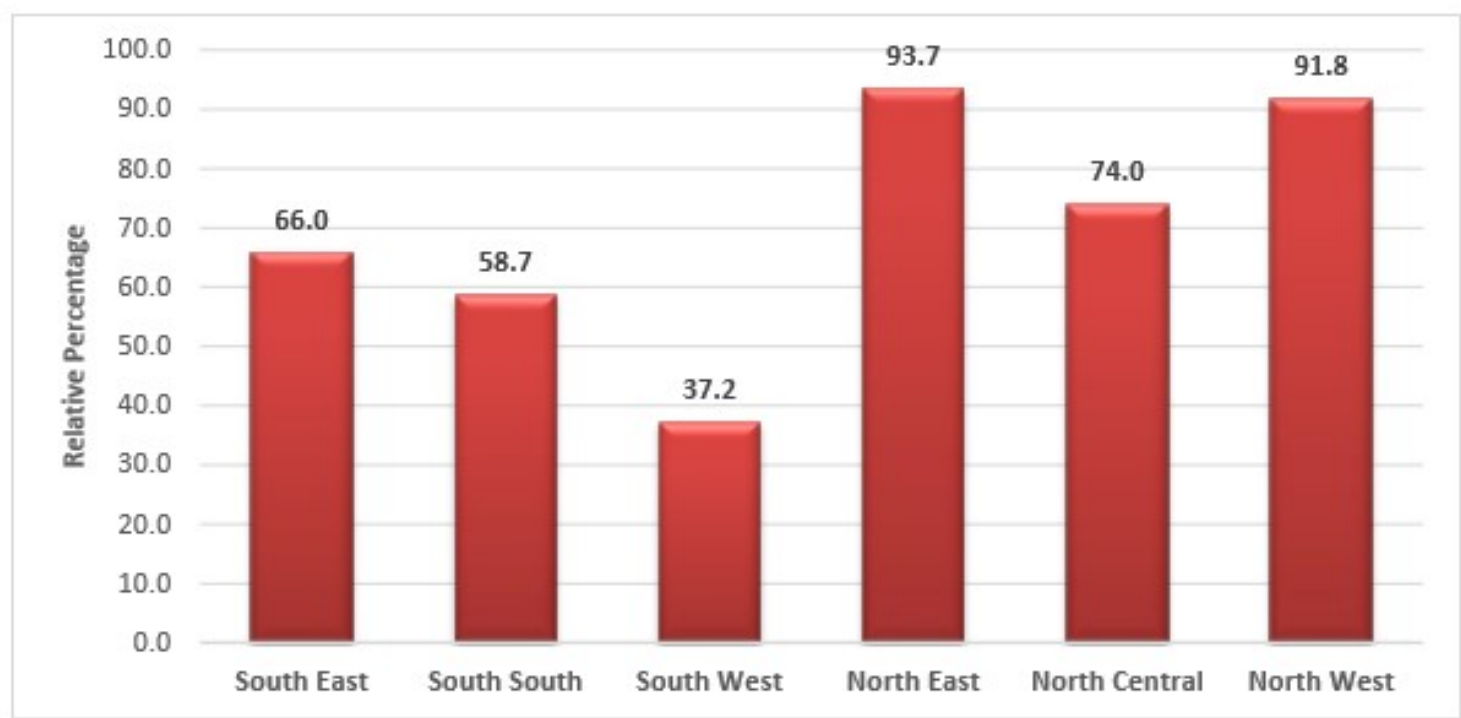

Figure 6: \% of Households Dependent on Firewood for Cooking by Regions in Nigeria (NBS, 2011) 